\title{
Influence of Livestock Grazing and Climate on Pinyon Pine (Pinus edulis) Dynamics
}

\author{
Nichole N. Barger, ${ }^{1}$ Henry D. Adams, ${ }^{2}$ Connie Woodhouse, ${ }^{3}$ Jason C. Neff, ${ }^{4}$ and Gregory P. Asner ${ }^{5}$
}

Authors are ${ }^{1}$ Assistant Professor, Department of Ecology and Evolutionary Biology, University of Colorado at Boulder, Boulder, CO 80309, USA;

${ }^{2}$ Graduate Research Assistant, Ecology and Evolutionary Biology, University of Arizona, Tucson, AZ 85721, USA; ${ }^{3}$ Associate Professor, Department of Geography and Regional Development, University of Arizona, Tucson, AZ 85721, USA; ${ }^{4}$ Associate Professor, Geological Sciences Department and

Environmental Studies Program, University of Colorado at Boulder, Boulder, CO 80309, USA; and ${ }^{5}$ Faculty Scientist, Department of Global Ecology, Carnegie Institution, Stanford, CA 94305, USA.

\begin{abstract}
Over the last century there has been marked expansion and infilling of pinyon (Pinus spp.)-juniper (Juniperus spp.) woodlands into grassland and shrubland ecosystems across the western United States. Although range expansions in pinyon-juniper populations have been documented with changing climate throughout the Holocene, over the last century, local scale impacts such as livestock grazing, changes in fire regimes, and increasing atmospheric $\mathrm{CO}_{2}$ concentrations are thought to be more recent drivers of pinyon-juniper woodland distribution. Our objective was to examine the role of historical livestock grazing relative to past climate in regulating pinyon (Pinus edulis Engelm.) recruitment and growth over the last century in a persistent pinyon-juniper woodland. We compared pinyon dynamics on a remote mesa site, minimally grazed by domestic livestock, to a nearby historically grazed site in southeastern Utah. The presence of a significant number of old trees $(>200 \mathrm{yr})$ at both sites suggests that these populations were well established prior to the 20th century. No differences in pinyon density or basal area were observed between grazed and ungrazed sites. Stand age structure data showed that pinyon recruitment across these sites was highly synchronous, with a large recruitment event occurring during the early 1900 s; $17 \%$ of the pinyons on both sites dated to the 1920 s. Climatic conditions during this decade were consistently cool and wet—conditions known to support enhanced recruitment and growth in pinyon pines. Pinyon growth was also strongly synchronous across sites $(r=0.96)$. Pinyon growth was significantly correlated with winter/spring precipitation and negatively correlated with June temperature. Taken together, our results suggest that past climate may be more important in structuring pinyon populations than historical land use in these persistent pinyon-juniper woodlands. Given future climate projections of increasing temperature and more extended drought periods, regeneration of pinyon populations following the recent regional-scale dieback may be slow. Moreover, prolonged drought combined with potentially slow regeneration times for pinyon under future climate scenarios could result in substantial declines in pinyon populations across the region, a result that land managers should consider when planning for future restoration treatments in persistent pinyon-juniper woodlands.
\end{abstract}

\section{Resumen}

Durante el último siglo se ha presentado una marcada expansión y establecimiento de bosques de piñón (Pinus spp.)-junípero (Juniperus spp.) dentro de ecosistemas de pastizales y matorrales a través del oeste de Estados Unidos. Aunque el rango de expansión en las poblaciones de piñón-junípero se ha documentado con cambios en el clima a través de los últimos años; durante el último siglo, los impactos a escala local como pastoreo de ganado, cambios en regímenes de fuego y el incremento de las concentraciones de $\mathrm{CO}_{2}$ en la atmósfera, se cree que son los más recientes responsables de la distribución de los bosques de piñón-junípero. Nuestro objetivo fue examinar la función histórica del pastoreo de ganado en relación con las condiciones climáticas presentadas en el pasado, sobre la regulación de piñón (Pinus edulis Engelm.) analizando su crecimiento durante el último siglo en un bosque persistente de piñónjunípero. Comparamos la dinámica del piñón en un sitio de una remota meseta, mínimamente pastoreada por ganado doméstico, con sitios cercanos pastoreados históricamente en el sureste de Utah. La presencia de un número significativo de arboles mayores de (>200 años) en ambos lugares sugiere que estas poblaciones fueron bien establecidas con anterioridad al siglo XX. No se encontró diferencias en la densidad de pinos o en el tamaño de su área basal analizada entre sitios pastoreados y no pastoreados. Los datos de la estructura de la edad de la población mostraron que los árboles evaluados en estos sitios fueron altamente sincronizados, con una gran cantidad de eventos que ocurrieron a principios de 1900; 17\% de los piñones en ambos sitios datan de la década de 1920. Condiciones climáticas durante esta década fueron consistententemente frías y húmedas—estas condiciones sirvieron para apoyar el mayor número de incorporación y desarrollo de los pinos piñoneros. El desarrollo de los piñoneros estuvo también fuertemente sincronizado entre los diferentes sitios $(\mathrm{r}=0.96)$. El crecimiento de los piñoneros se relacionó significativamente con la precipitación de invierno/primavera y negativamente correlacionado con la temperatura del mes de junio. Agrupando, nuestros resultados sugieren que las condiciones climáticas presentadas en el pasado podrían ser más importantes en la estructura de las poblaciones de los pinos piñoneros que el uso histórico de la tierra realizado en los bosques de juníperos. Dadas la futuras proyecciones climáticas sobre el incremento en la temperatura así como mayores y más prolongados periodos de sequia, la regeneración de las poblaciones de piñones

Research was funded by the National Park Ecological Research Fellowship (NPER) and NASA NRA-04-OES-01 Carbon Cycle Science Program.

Mention of a proprietary product does not constitute a guarantee or warranty of the product by USDA or the authors and does not imply its approval to the exclusion of the other products that also may be suitable.

At the time of the research, Barger was a research associate at the Institute of Arctic and Alpine Research, University of Colorado at Boulder, Boulder, CO 80309, USA

Correspondence: Nichole N. Barger, Dept of Ecology and Evolutionary Biology, University of Colorado at Boulder, CB 334, Boulder, CO 80309, USA. Email: nichole.barger@colorado.edu

Manuscript received 13 March 2009; manuscript accepted 2 September 2009. 
siguiendo la reciente escala-regional la muerte regresiva puede ser lenta. Además, de las sequias prolongadas y la combinación con periodos de regeneración potencialmente lentos para los piñones, bajo un escenario cambios climáticos a futuro esto podrían resultar en una principal disminución en las poblaciones de piñonero en la región, como resultado los manejadores de estas áreas deberían considererarlo a la hora de planear futuros tratamientos de restauración en bosques persistentes de piñón-junípero.

Key Words: age structure, climate change, Grand Staircase-Escalante National Monument, land use change, pinyon, tree growth, tree ring, woodland expansion, woody encroachment

\section{INTRODUCTION}

Over the last several decades it has become widely recognized that increasing dominance of woody plants over herbaceous plant species is occurring at rapid rates across a diverse range of ecosystems globally (e.g., Archer 1994; Miller and Wigand 1994; Van Auken 2000; Briggs et al. 2005; Fensham et al. 2005; Andersen and Baker 2006; Dalle et al. 2006). Of particular importance to the management of western United States public lands has been the expansion and infilling or "thickening" of pinyon pine (Pinus spp.) and juniper (Juniperus spp.) populations, a pattern observed over the last century across widely diverse climatic regimes, soil types, and understory vegetation communities (Blackburn and Tueller 1970; Miller and Wigand 1994; Miller and Rose 1999; Tausch and Nowak 1999; Wall et al. 2001; Weisberg et al. 2007).

Throughout the Holocene, pinyon and juniper species have fluctuated along elevational and latitudinal gradients-dynamics that have generally been linked to changing climate throughout this period (Van Devender and Spaulding 1979; Betancourt 1990; Nowak et al. 1994; Wigand et al. 1995; Jackson et al. 2005; Gray et al. 2006). Past pinyon-juniper range expansions generally occurred during cooler, wetter time periods with warm, dry periods resulting in woodland declines and replacement by grasslands and desert shrub communities (see review by Tausch 1999). During the last century a number of human caused changes, such as declines in the use of fire by Native Americans, the large-scale introduction of domestic livestock grazing by Euro-American settlers and subsequent increases in fire return intervals, and increasing atmospheric $\mathrm{CO}_{2}$ concentrations all in combination with favorable climatic conditions are believed to have set up the conditions for rapid expansion of pinyon-juniper populations across western landscapes (Miller and Wigand 1994; Tausch 1999).

Of the changes that occurred across these landscapes during the late 19th into the early 20th century, the most extensive impacts on plant communities came from the large-scale introduction of domestic livestock grazing (Pieper 1994). The timing of the introduction of livestock in record numbers coincided with cooler, wetter conditions across the West in the early 20th century (Hereford et al. 2002; Gray et al. 2006), conditions that were favorable for tree establishment. Thus the question still remains as to whether widespread expansion and infilling across the range of pinyon-juniper woodland types was driven by past climate, changing land use with the large-scale introduction of domestic livestock, or the likely scenario a combination of these factors. Resolution of these questions has clear relevance to the management of a dominant vegetation type of the western United States.

Pinyon-juniper woodlands occur across a diverse array of climatic regimes, soil types, and understory plant communities: in southern Utah alone, there are over 20 distinct ecological site types where pinyon and juniper species are the dominant overstory component (http://www.ut.nrcs.usda.gov/technical/ technology/range/ecosites.html). Thus efforts to more broadly understand the important drivers leading to the observed changes in pinyon-juniper woodland dynamics over the last century have often been confounded by the highly variable climatic regimes, understory vegetation structure, and historic disturbance regimes across these ecosystems.

Following this, our objective in this study was to compare the role of historical livestock grazing and past climate to better understand how these factors have influenced modern pinyon (Pinus edulis Engelm.) distributions in two upland sites (2 000$2200 \mathrm{~m}$ in elevation) on the Colorado Plateau that differed in historical land use. Vegetation structure at these sites can best be described as upland "persistent" woodlands (Jacobs et al. 2008; Romme et al. 2008), which are characterized by low understory plant cover, variable tree cover ranging from small sparsely distributed trees occurring on low productivity sites to closed canopy dense stands occurring at more productive sites, and fire return intervals on century to multicentury time scales (Romme et al. 2008). As the term "persistent" suggests, these areas often maintain significant presence of pinyon and juniper species over several hundred years, and the more recent changes in the structure of these woodlands over the last century have been recruitment into interspaces between older trees or "infilling" as opposed to expansion into adjacent vegetation types. The persistent pinyon-juniper woodland type is found throughout the western United Sates and is particularly well represented across large expanses of the Colorado Plateau.

Our study was conducted at Grand Staircase-Escalante National Monument in southern Utah at a paired historically grazed and relatively ungrazed protected site. Historical photos from these sites showed dramatic tree cover increases over the last 70 years (Harris et al. 2003). Previous research at these sites showed that total tree cover (Pinus edulis Engelm. and Juniperus osteosperma [Torr.] Little) was similar across these sites (Harris et al. 2003; Guenther et al. 2004) but that pinyon cover was nearly twofold higher at the historically grazed site as compared to the minimally grazed protected site (Guenther et al. 2004). As a result, we focused our research efforts on changes in pinyon pine recruitment and growth dynamics over the last 150 years-the time period since the large-scale introduction of domestic livestock.

Here we addressed the question, is there evidence that the large-scale introduction of domestic livestock in the late 1800 s resulted in increased recruitment and growth of pinyon pine in persistent woodlands? There are a number of proposed mechanisms by which trees may outcompete herbaceous plant communities under grazing, such as reduction of fine fuels and subsequent increases in fire return intervals, decreased competition for soil resources with removal of understory plants, and increasing shrub density, which serve as nurse plants for trees (Miller and Wigand 1994; Tausch 1999). If the introduction of 
livestock to these areas in the 1800 s was an important driver of pinyon population dynamics at these sites, we would expect to observe enhanced recruitment and growth at historically grazed sites during the mid-1800s into the early 1900s as compared to the minimally grazed relict site.

Synchronous pinyon recruitment and growth dynamics across sites that differed in historical livestock grazing, however, would suggest that more regional scale factors such as climate may be the important driver of pinyon-juniper expansion over the last century. Following this, we addressed a second question: How has past climate influenced pinyon recruitment and growth dynamics? Climatic variables that influence pinyon recruitment differ from those that influence annual growth. Successful pinyon recruitment is dependent on a complex set of abiotic and biotic factors that regulate initiation of cone production through seed production and subsequent germination, a process that takes three years to complete. Cool and wet climatic conditions have been shown to be generally favorable for pinyon cone production and subsequent seed germination and establishment (Forcella 1981; Chambers et al. 1999). Thus we would expect that climate-driven pinyon recruitment events should generally occur during cool-wet time periods that persist over multiple years. In contrast to pinyon recruitment, pinyon growth has been shown to be mostly responsive to winter and early spring precipitation of the current growing season (Fritts et al. 1965; Adams and Kolb 2005).

\section{METHODS}

\section{Study Site}

This study was conducted in 2005 within Grand StaircaseEscalante National Monument (GSENM), which is located in southern Utah near the Arizona border. Sites were located within the Grand Staircase geographic section of the monument, which is characterized by a succession of geologic cliffs and benches that increase in elevation, crossing a range of substrates from south to north (Doelling et al. 2000). To examine the role of historical land use on pinyon pine dynamics over the last century, we located pinyon-juniper woodland sites within GSENM that differed in past land use but occurred in areas with similar substrates, topography, elevation, and climate. No Man's Mesa (NMM; lat $37^{\circ} 19^{\prime} 28^{\prime \prime} \mathrm{N}$, long $112^{\circ} 06^{\prime} 54^{\prime \prime} \mathrm{W}$ ) is a 715 -ha wilderness study area within GSENM that has experienced very little domestic livestock grazing over the last century. The steep cliffs surrounding the mesa top make this area relatively inaccessible to domestic livestock. The only documented domestic grazing on NMM was a period of goat grazing during the late 1920s. A trail was built to the top of NMM in 1927, and 800 goats were relocated to the top of the mesa. The following spring 1300-1500 wether goats grazed the mesa for approximately six weeks (Mason et al. 1967). Based on the area of NMM, the stocking rate was approximately 1-2 goats $\cdot \mathrm{ha}^{-1}$ during that time period.

We paired this relatively ungrazed mesa site with Deer Spring Point (DSP; lat $37^{\circ} 17^{\prime} 56^{\prime \prime} \mathrm{N}$, long $112^{\circ} 10^{\prime} 12^{\prime \prime} \mathrm{W}$ ), a site located approximately $2.5 \mathrm{~km}$ southwest of NMM that has been grazed by domestic livestock since the mid-1800s (Guenther et al. 2004). Although exact numbers for livestock are not available for DSP, inferences may be drawn from the history of grazing in the region. Grazing was first introduced to southern Utah in the
Table 1. Topographic and physical soil characteristics on the minimally grazed No Man's Mesa as compared to historically grazed sites at Deer Spring Point. Values are means calculated across six transects at each site.

\begin{tabular}{lcc}
\hline & No Man's Mesa & Deer Spring Point \\
\hline Elevation $(\mathrm{m})$ & 2139 & 2169 \\
$\quad \%$ slope & 5.7 & 5.7 \\
Aspect at transect stops & & \\
\% north-facing & 68 & 67 \\
$\%$ south-facing & 4 & 5 \\
$\%$ east-facing & 14 & 14 \\
$\%$ west-facing & 14 & 14 \\
Soil texture & & \\
$\%$ sand & 91 & 89 \\
$\%$ silt & 6 & 7 \\
$\%$ clay & 3 & 4 \\
\hline
\end{tabular}

1860s. By 1913, an estimated 113000 sheep and 15000 cattle were located within Kane County, a $10641-\mathrm{km}^{2}$ area in southern Utah in which our sites are located (http://www.nps.gov/glca/ naturescience/grazing.htm). These pinyon-juniper woodland sites are generally considered to be fair on the spectrum of poor to excellent in providing forage for domestic livestock.

Both NMM and DSP receive on average $360 \mathrm{~mm}$ of precipitation each year and are located at an elevation ranging from $2000 \mathrm{~m}$ to $2200 \mathrm{~m}$ (Table 1). Bedrock geology and soil classification maps in a Geographic Information System were used to establish transects on similar soil and geologic settings on NMM and DSP. Six transects were established at each of the sites. Each transect was $300 \mathrm{~m}$ in length with sampling points occurring at 25-m intervals. Soils are derived from eolian and alluvial Carmel-Page Formation sandstone and classified as Pinepoint soils, which are well-drained sandy soils with sand content ranging from $85 \%$ to $90 \%$ across all transects (Table 1). Pinyon pines are co-dominant with Utah juniper $(J$. osteosperma) at these sites.

\section{Pinyon Population Structure}

Population structure of pinyons at our sites was examined by estimating density, basal area, and age across each of the transects. Absolute density of pinyon was estimated using the point-centered quarter method (PCQ). PCQ is a plotless method to estimate tree density, which is generated from "nearest neighbor" measurements and is generally less time consuming and requires fewer sampling points to adequately capture population densities compared to plot-based methods (Pollard 1971). At each transect stop, we divided the area into four quarters along a north-south and east-west line. The distance from the transect stop to the nearest tree (defined as $>4 \mathrm{~cm}$ diameter at the root collar) was measured within each of the quarters. Pinyon density was then calculated based on the density estimator:

$$
D \approx \frac{3}{\pi\left(r_{i}^{2}\right)},
$$

where $D$ is pinyon density and $r_{i}$ is the average distance in meters to the nearest tree across the four quarters (Pollard 
1971). To avoid biased estimates of densities due to nonuniform tree density, we calculated a density estimator at each transect stop as opposed to the transect as a whole, which has been shown to be a less biased estimator of population density in nonuniform forests (Jost 1993). Tree diameter was measured at 10-15 cm height on each of the trees with a dbh tape, which converts measurements of tree circumference to diameter. These measurements were used to estimate basal area of pinyons at each site. Basal area for each tree was calculated using the equation

$$
G=\pi_{4}^{d^{2}}
$$

where $G$ is the basal area of the nearest pinyon in each quarter and $d$ is the diameter in centimeters. The four basal area estimates for each stop were then averaged and multiplied by the density value for that location to obtain an estimate of pinyon basal area along each transect.

Tree age was estimated using dendrochronology or tree ring dating techniques. An increment borer was used to collect cores from each of the pinyon trees within each sampling quarter $(n=52$ at each transect). Cores were collected approximately $10-15 \mathrm{~cm}$ above the ground. Tree cores were analyzed at the Institute for Arctic and Alpine Research's Dendrochronology Lab, University of Colorado, Boulder. Increment cores were mounted (Stokes and Smiley 1968) and progressively sanded with FEPA (Federation of European Producers of Abrasives) 120-, 220-, 320-, and 400-grit (162, 68, 44.7-47.7, and 33.5$36.5 \mu \mathrm{m}$, respectively; Orvis and Grissino-Mayer 2002) sandpaper using a Bosch belt sander (Robert Bosch Corp., Farmington Hills, MI). Cores were also hand-surfaced using 400-grit and 1200-grit sandpaper $(33.5-36.5 \mu \mathrm{m})$. Cores were then visually cross-dated using a previously developed pinyon chronology for NMM (C. Woodhouse, unpublished data, 2003). For samples difficult to visually cross-date, undated inner sections were run against the previously developed chronology using COFECHA (Holmes 1983). COFECHA is a software program used to check the quality of the cross-dating. All matching dates found using the COFECHA program were then visually verified. We recorded the first year of secondary growth to calculate tree age. Although we made three to five attempts in the field to obtain cores that included pith, we were not always successful. We estimated dates for cores without pith by overlaying sets of concentric circles on the inner rings of the core (Applequist 1958). To correct for the time to coring height, we collected pinyon seedlings from a range of sites and soil types across the region. Average time to a coring height of $15 \mathrm{~cm}$ is approximately $11 \mathrm{yr}$. Once an inner ring date was obtained from the cores, $11 \mathrm{yr}$ was subtracted from this date to correct for the time to coring height.

\section{Pinyon Growth}

We examined the relationship between pinyon growth and past climate at our sites. We measured tree-ring width on a Velmex ring width measuring system at the Institute of Arctic and Alpine Research at the University of Colorado at Boulder. One pinyon tree core from each transect stop was chosen for ring width measurement. Of this subset, we chose only those trees that were older than 1950 to be in the chronology for a sample
Table 2. Pinyon pine stand structure at historically ungrazed sites (No Man's Mesa) as compared to historically grazed sites (Deer Spring Point). Values are means with standard errors in parentheses. Differences in letters denote statistical differences in mean values evaluated at $P<0.05$.

\begin{tabular}{lcc}
\hline & No Man's Mesa & Deer Spring Point \\
\hline Density $\left(\right.$ pinyons $\left.\cdot \mathrm{ha}^{-1}\right)$ & $282(113)$ & $295(41)$ \\
Diameter at $10 \mathrm{~cm}(\mathrm{~cm})$ & $19.9(1.2)$ & $20.6(1.1)$ \\
Basal area $\left(\mathrm{m}^{2} \cdot \mathrm{ha}^{-1}\right)$ & $8.7(3.9)$ & $13.2(2.6)$ \\
Mean tree age $(\mathrm{yr})$ & $124(5)^{\mathrm{a}}$ & $157(7)^{\mathrm{b}}$ \\
Average diameter growth rate & & \\
$\quad\left(\mathrm{cm} \cdot \mathrm{yr}^{-1}\right)$ & $0.20(0.02)$ & $0.17(0.02)$ \\
Establishment year of oldest trees & $1589(63)$ & $1587(59)$ \\
\hline
\end{tabular}

size of 62 and 52 for NMM and DSP, respectively. Raw ring widths were reported to $0.001 \mathrm{~mm}$. To enhance the environmental growth signal from the pinyon populations, raw ring widths were standardized using the software program ARSTAN 6.05P (Cook 1985). Within ARSTAN, series data were first detrended with a negative exponential function, a type of growth curve observed across a range of organisms. If this growth function failed to adequately model changes in growth rates over time, then the series was modeled with a linear regression. Raw ring width was divided by the "expected" or modeled value to obtain detrended values in the series. Biweight means were then calculated for each year to create a site chronology. These values were then compared to average precipitation and temperature values for the previous October through August of the current growing season.

\section{Statistical Analyses}

We used a Student's $t$-test to examine the role of historical livestock grazing in structuring the pinyon populations by comparing pinyon density, basal area, and growth rates across historically grazed (DSP) and minimally grazed sites (NMM). Pearson's correlation coefficients were calculated to examine the strength of the relationship between pinyon recruitment and growth to monthly climatic variables. Divisional climate data for southeastern Utah (Division 7) for years 1896-2007 were obtained from the National Oceanic and Atmospheric Administration National Climate Data Center (http://www7.ncdc. noaa.gov/CDO/CDODivisionalSelect.jsp). SPSS 16.0 was used in all statistical analyses (SPSS 2007).

\section{RESULTS}

\section{Pinyon Recruitment}

The oldest trees at our sites dated to time periods before EuroAmerican settlement (Table 2), suggesting that pinyons have been present at these sites for more than 200 years $(\mathrm{min} / \mathrm{max}$ oldest tree date across 6 transects, $\mathrm{NMM}=1360 / 1780$, DSP $=1450 / 1790$ ). Pinyon stand structure was similar at NMM and DSP, with no observed differences in density or basal area between these sites (Table 2). Mean tree age, however, was significantly older at DSP relative to NMM (Table 2). Differences in mean tree age were primarily due to the greater number of trees at DSP that dated to time periods before 1700 as compared 

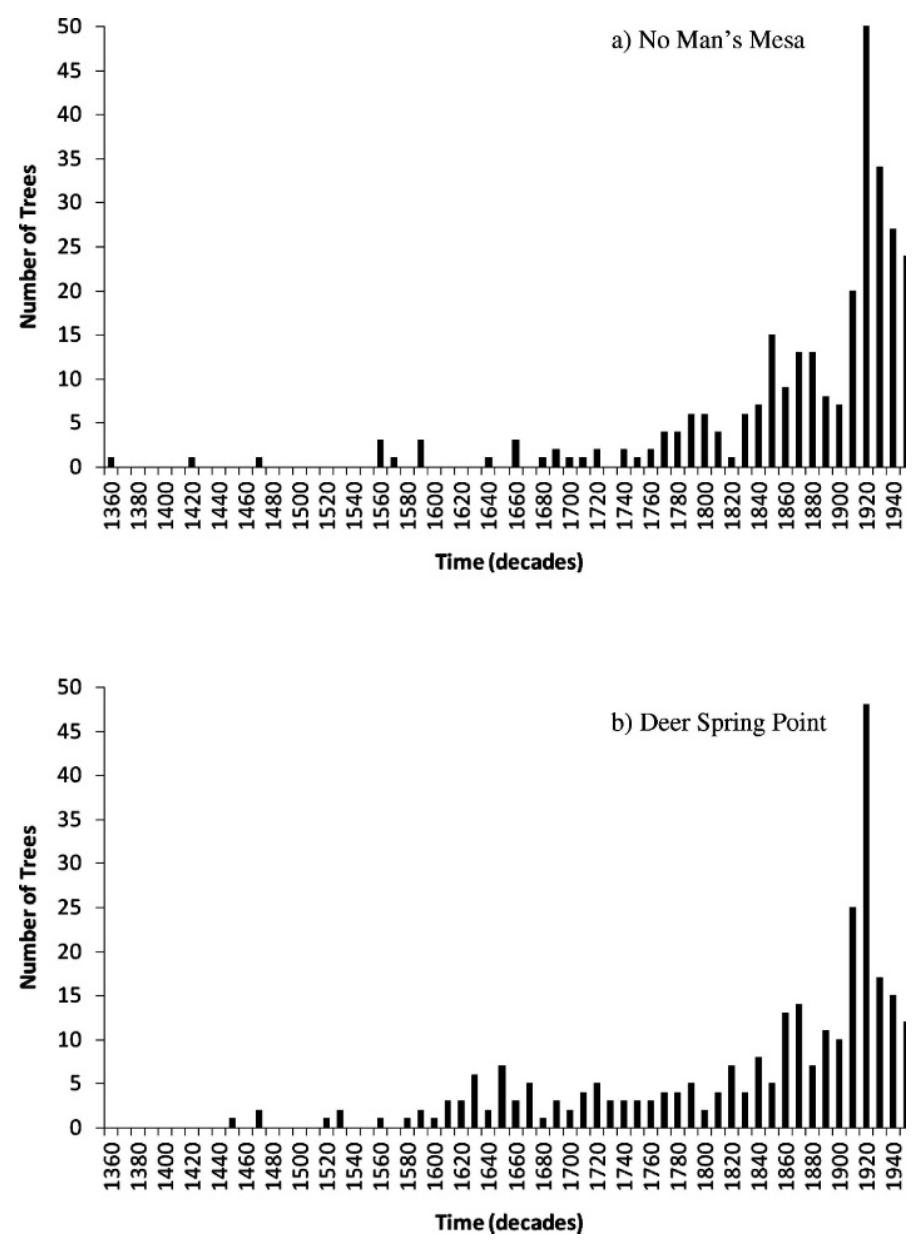

Figure 1. Pinyon recruitment at a) No Man's Mesa and b) Deer Spring Point. Only trees $>4 \mathrm{~cm}$ in diameter were aged; thus pinyon recruitment over the last several decades (1960-present) was not estimated.

to NMM (DSP $=41, \mathrm{NMM}=17$ ). Although there were differences in mean tree age, the proportion of old trees dating to presettlement time periods was similar across the two sites: $36 \%$ and $38 \%$ of the trees dated to periods before the 1850 s across NMM and DSP, respectively (Fig. 1).

Recruitment dynamics were highly correlated between the two sites (Fig. 2; $r=0.88, P=0.003$ ). Of particular interest, our data show a large pulse in recruitment during the 1920s; $17 \%$ of the trees sampled across both sites dated to the period of 1920-1929 (Fig. 1). Climatic conditions during this time period were consistently cool and wet (Fig. 3). During the period 1920-1929, average growing season temperature and annual precipitation were below and above normal in 7 and 8 of the 10 years, respectively.

\section{Pinyon Growth}

Similar to pinyon recruitment, pinyon growth dynamics were similar at NMM and DSP. Average pinyon growth rates (tree diameter/age) between NMM and DSP were not significantly different, averaging 0.20 and $0.17 \mathrm{~cm} \cdot \mathrm{yr}^{-1}$, respectively (Table 2). Furthermore, annual growth across these sites was highly correlated (Fig. $4 ; r=0.94, P<0.001$ ). These data taken together suggest that the introduction of livestock did

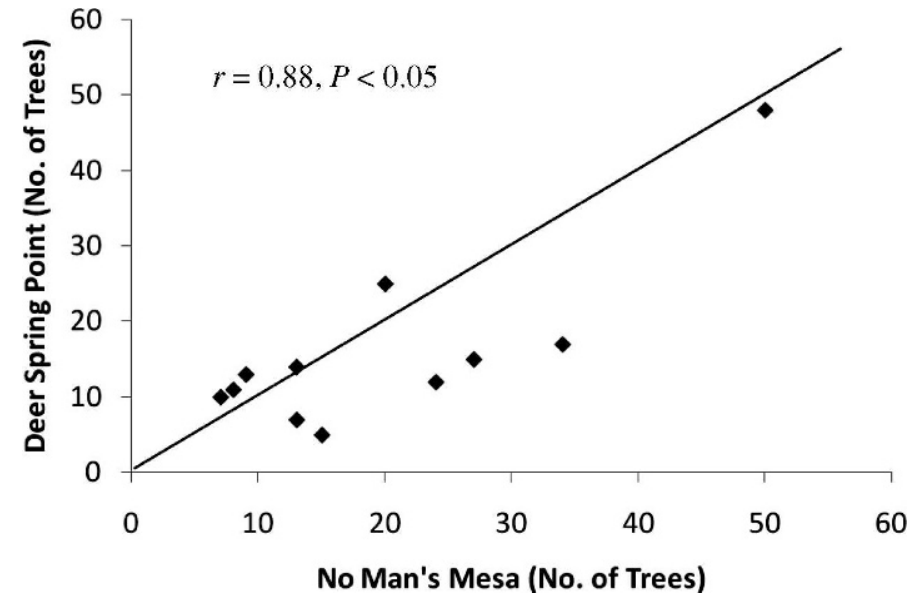

Figure 2. Correlation of pinyon recruitment dynamics (trees/decade) across No Man's Mesa and Deer Spring Point for the period 1850-1950, the period when heavy livestock grazing has been estimated to have occurred across the western United States. A 1:1 line is shown for comparison.

not significantly impact pinyon growth rates over the last 150 yr. Pinyon growth rates, however, were strongly influenced by winter through early summer precipitation (Fig. 5). At NMM and DSP, pinyon growth was positively correlated with precipitation levels in the previous October-to-June period and negatively correlated with June temperature (Fig. 5).
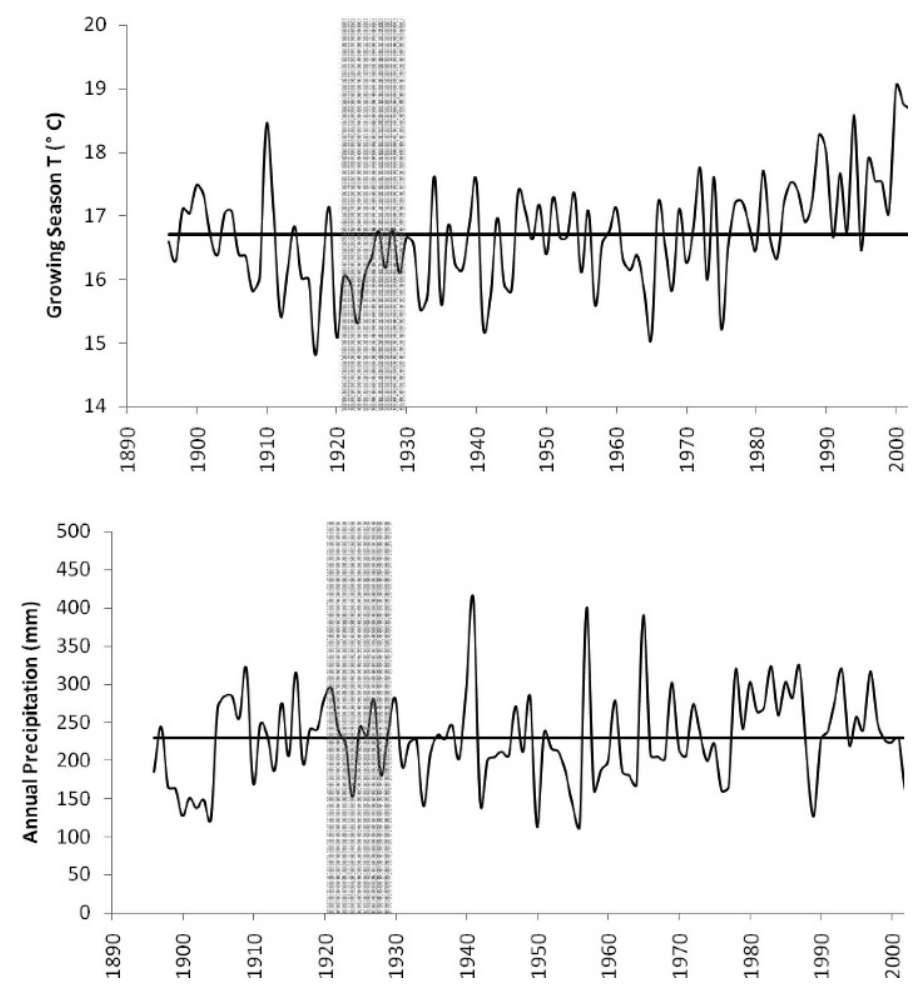

Figure 3. Total annual precipitation and average growing season temperature (March-August) record for southern Utah (Division 7). Solid horizontal lines represent the mean across the period of 18962007. The transparent gray bar indicates the time period of the large pinyon recruitment event at our sites. 


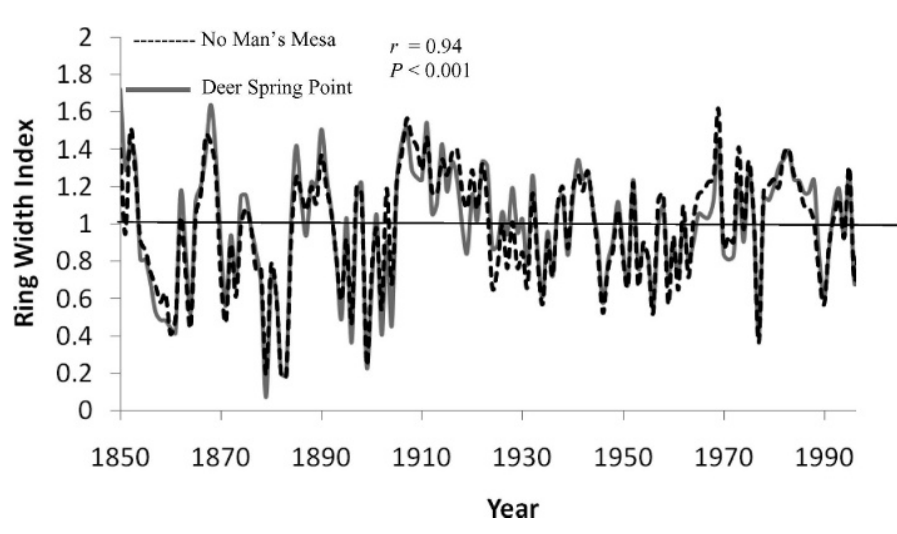

Figure 4. Pinyon growth from 1850 to 2005 at historically grazed (No Man's Mesa) and ungrazed (Deer Spring Point) sites. Tree ring values are standardized ring widths.

\section{DISCUSSION}

\section{Role of Historical Livestock Grazing in Pinyon Recruitment and Growth}

Livestock grazing has clearly played a role in promoting woody expansion and infilling across a range of ecosystems globally (Cottam and Stewart 1940; Madany and West 1983; Soulé et al. 2003; Tefera et al. 2007; Schlecht et al. 2009). Historical livestock grazing, however, appears to have been less important than past climate in structuring the pinyon population within the persistent pinyon-juniper woodland sites in our study. Pinyon recruitment and growth dynamics were highly correlated across sites that differed in past land use, and evidence of a large-scale recruitment event during a cool, wet climatic period suggests that climate during the early-20th-century wet period may have played an important role in structuring the modern pinyon population. The enhanced early century pinyon recruitment dynamics in our study are similar to those reported for the Uncompahgre Plateau in western Colorado, which suggests that conditions were favorable for pinyon establishment across the region (Eisenhart 2004). Other studies have observed similar patterns in recruitment whereby recent expansion of woody plants was strongly regulated by climate and the role of historical livestock grazing was negligible (Silva et al. 2001; Fensham et al. 2005). It is important to note, however, that limited goat grazing did occur in the late 1920 s on NMM (1927-1928), and this grazing event cannot be ruled out as having an influence on pinyon recruitment and growth dynamics on NMM during the 1920s.

Declines in grass and herbaceous understory under intensive livestock grazing, which may influence tree-grass competition and increase fire return intervals, have been hypothesized as important mechanisms by which trees outcompete grasses and herbaceous species (Miller and Wigand 1994). Given the low levels of herbaceous cover available for livestock grazing across persistent pinyon-juniper woodlands (Romme et al. 2008) and historic fire regimes that are characterized by stand-replacing fires on a rotation upwards of $400 \mathrm{yr}$ at sites similar to ours in the region (Floyd et al. 2000, 2004), it is unlikely that the competitive environment and historic fire regime were significantly altered with the introduction of livestock in the late 1800s. Grass and herbaceous understory cover at these sites ranged from $5 \%$ to $6 \%$

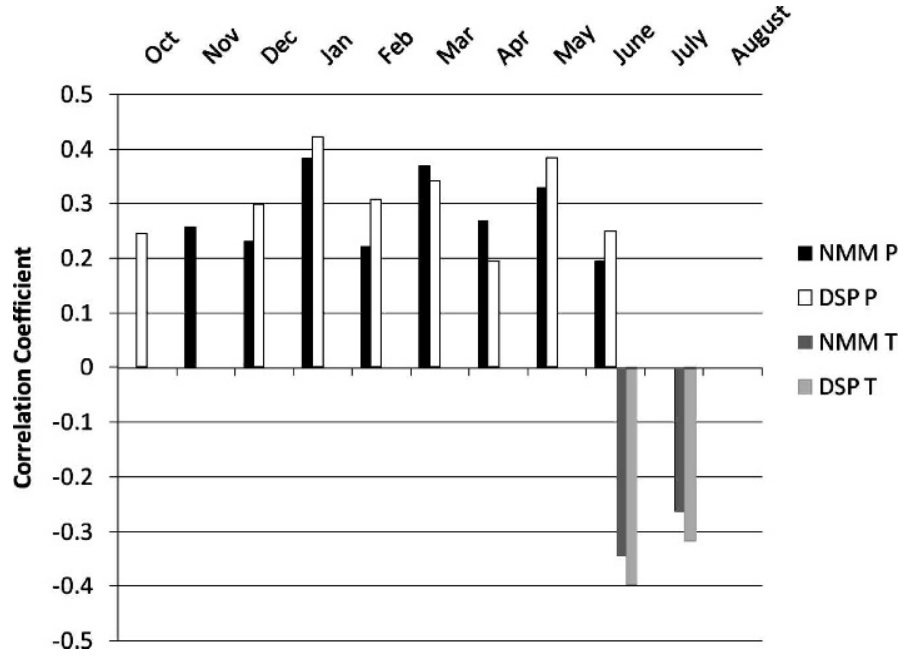

Figure 5. Correlation of pinyon growth to monthly climatic variables over the period 1896-2005 for the relatively ungrazed No Man's Mesa (NMM) site and the historically grazed Deer Spring Point (DSP) site. Pinyon standardized ring widths were correlated with average monthly temperature $(\mathrm{T})$ and precipitation $(\mathrm{P})$ during 11 months. Late fall and winter climatic variables (October-March) were previous to the current growing season. Late spring and summer climatic variables (April-August) were during the current growing season. Only correlation coefficients that were statistically significant at levels of $P<0.05$ are shown.

in a recent study (Guenther et al. 2004), values that are in the range of what we would expect to observe in this Upland Shallow Loam (Pinyon-Juniper) ecological site (ftp://ftp-fc.sc.egov.usda. gov/UT/Range/D35XY/035XY315UT.pdf). Although fire history was not reconstructed for these sites, our stand age structure data suggest that no large stand-replacing fires have occurred across these sites for at least 200 yr. Oldest tree dates for all NMM and DSP transects were similar and ranged from 1362 to 1788 and 1437 to 1797 , respectively. Results from a recent study by Floyd et al. (2008) conducted at similar pinyon-juniper sites in southern Utah showed no alteration of historic fire regimes after a century of livestock grazing and fire suppression policies.

\section{Importance of Climate in Regulating Pinyon Populations}

In our study, pinyon recruitment was strongly synchronous across sites that differed in historical livestock grazing, suggesting that more regional scale factors such as climate were more important in structuring the modern pinyon population. Large recruitment events, such as the one that occurred in the pinyon population during the 1920s, may have a disproportionate effect on structuring pinyon-juniper woodlands. Nearly one out of every five pinyons sampled across our sites recruited in the 1920s. The period of cooler, wetter conditions began in the decade previous to the 1920s and continued into the early years of that decade. These conditions have been observed in the climate record of southern Utah (Fig. 3) and across much of the Southwest (Ni et al. 2002). This early-20th-century wet period was preceded by a multiyear drought at the turn of the century (1896-1904), which may have resulted in regional tree mortality, thus setting the stage for a regional recruitment event (Plummer 1904; Phillips 1909). Large-scale recruitment of other western forest species such as ponderosa pine (Pinus ponderosa) occurred across much of the 
Southwest United States during this same time period (Savage et al. 1996; Brown and Wu 2005).

If multiyear cool, wet periods are needed for large-scale pinyon establishment events, what are the potential implications for future recruitment events among pinyon populations in this region given projections of warmer and drier conditions across the West? Our sites have experienced a $0.7^{\circ} \mathrm{C}$ average increase in growing season temperature in the last 50 years as compared to the previous half century (Fig. 3; 1900-1950 average $=16.4^{\circ} \mathrm{C}$, 1958-2007 average $=17 \cdot 1^{\circ} \mathrm{C}$ ). Taken with the climate projections of increasing temperatures, more prolonged drought periods, and a general increase in aridity across the region (Christiansen et al. 2007; Seager et al. 2007), it is possible that large pinyon recruitment events, such as the one documented in the 1920s at our sites, will be less frequent in the future. Indeed, studies of $P$. edulis masting events across central New Mexico showed declines in seed production during the most recent multiyear drought (1997-2004; Zlotin and Parmenter 2008).

As we predicted, pinyon growth was positively correlated with winter through early summer precipitation. Most interestingly, pinyon growth was also negatively correlated with June temperature. This negative correlation is likely due to drought stress incurred during the driest month of the growing season before the onset of the summer monsoon, whereby higher temperatures impact available soil water through evaporative processes. In this region of the Colorado Plateau, the first xylem cells in pinyon are just being formed during the last week of May (Fritts 2001); thus environmental conditions during this period are critically important for pinyon growth. Recent regional pinyon tree ring analyses (N. N. Barger and C. Woodhouse, unpublished data [in prep], 2009) suggest that this effect of summer temperature is a trend that has been observed over the last several decades that was not apparent early in the century.

Although there has been a general trend toward expansion of pinyon-juniper woodlands over the last century, in the last several years (i.e., 2000-2004) a multiyear drought has caused largescale dieback of pinyons throughout the Colorado Plateau (Breshears et al. 2005; Shaw 2006). Acknowledging the need for cool wet climatic conditions spread over several years to promote a large-scale pinyon recruitment, it is likely that with future climate projections of increasing temperature and more extended drought periods, future regeneration of pinyon populations following regional-scale dieback will be slow. Moreover, prolonged drought combined with potentially slow regeneration times for pinyon under future climate scenarios could result in substantial declines in pinyon populations, a result that land managers should consider when planning for future restoration treatments across these landscapes.

\section{Management Implications}

Pinyon-juniper ecosystems are the third largest vegetation type in the United States and one of the largest vegetation types administered by federal land management agencies. To date, nearly $7 \%$ of pinyon-juniper woodlands on the Colorado Plateau, many of which occur in persistent woodland sites such as ours, have been treated over the last several decades using a variety of methods to remove trees in efforts to restore pinyonjuniper ecosystems to a more historical condition. Our data suggest that the large pinyon recruitment event in the 1920s, trees that now make up a significant overstory component in these sites, was likely a natural or climate-driven event. Additionally, nearly one-third of the pinyons dated in our study established in presettlement time periods (before 1850), which suggests that pinyons have long been established at this site. Although these persistent woodland sites have been historically grazed by livestock and there is evidence from previous studies that cover and composition of the understory vegetation has been altered, in particular increases in shrub and declines in biological soil crust cover (Harris et al. 2003; Guenther et al. 2004), a recent study of the rangeland health attributes of pinyon-juniper woodlands in GSENM suggests that pinyon-juniper sites have been relatively unaffected by historical land use (Miller 2008). If one of the overarching management goals in mechanically treating persistent pinyonjuniper woodlands is to restore these ecosystems to a more historical condition, results from our study in addition to several others conducted in this woodland type on the Colorado Plateau suggest that anthropogenic changes in grazing and fire regimes have not played a significant role in structuring pinyon-juniper populations over the last century (Floyd et al. 2000; Eisenhart 2004; Floyd et al. 2008; Romme et al. 2008). Thus the call to restore mature, persistent pinyonjuniper woodland to a more historic condition using mechanical methods and prescribed fire must be closely scrutinized.

\section{ACKNOWLEDGMENTS}

We would like to thank Dan Fernandez, Zak Seligman, and Amanda Ochs for help in the field and preparation of the manuscript. We would also like to thank the two anonymous reviewers for providing extensive comments on the manuscript.

\section{LITERATURE CITED}

Adams, H. D., And T. E. Kolb. 2005. Tree growth response to drought and temperature in a mountain landscape in northern Arizona, USA. Journal of Biogeography 32:1629-1640.

Andersen, M. D., and W. L. Baker. 2006. Reconstructing landscape-scale tree invasion using survey notes in the Medicine Bow Mountains, Wyoming, USA. Landscape Ecology 21:243-258.

ApPlequist, M. B. 1958. A simple pith locator for use with off-center increment cores. Journal of Forestry 56:141.

ArCHeR, S. 1994. Woody plant encroachment into southwestern grasslands and savannas: rates, patterns and proximate causes. In: M. Vavra, W. A. Laycock, and R. D. Pieper [EDS.]. Ecological implications of livestock herbivory in the West. Denver, C0, USA: Society for Range Management. p. 13-68.

Betancourt, J. L. 1990. Late quaternary biogeography of the Colorado Plateau. In: J. L. Betancourt, T. R. Van Devender, and P. S. Martin [EDS.]. Packrat middens: the last 40,000 years of biotic change. Tucson, AZ, USA: University of Arizona Press. p. 259-292.

Blackburn, W. H., and P. T. Tueller. 1970. Pinyon and juniper invasion in black sagebrush communities in east-central Nevada. Ecology 51:841-848.

Breshears, D. D., N. S. Cobb, P. M. Rich, K. P. Price, C. D. Allen, R. G. Balice, W. H. Romme, J. H. Kastens, M. L. Floyd, J. Belnap, J. J. Anderson, O. B. Myers, And C. W. Meyer. 2005. Regional vegetation die-off in response to globalchange-type drought. Proceedings of the National Academy of Sciences of the United States of America 102:15144-15148.

Briggs, J. M., A. K. Knapp, J. M. Blair, J. L. Heisler, G. A. Hoch, M. S. Lett, and J. K. McCarron. 2005. An ecosystem in transition: causes and consequences of the conversion of mesic grassland to shrubland. Bioscience 55:243-254. 
Brown, P. M., And R. Wu. 2005. Climate and disturbance forcing of episodic tree recruitment in a southwestern ponderosa pine landscape. Ecology 86: 3030-3038.

Chambers, J. C., S. B. Vander Wall, and E. W. Schupp. 1999. Seed and seedling ecology of pinon and juniper species in the pygmy woodlands of western North America. Botanical Review 65:1-38.

Christiansen, J. H., A. Hewitson, A. Busuloc, A. Chen, X. Gao, I. Held, R. Jones, R. K. Kolli, W. T. Kwon, R. Laprise, V. Magana Rueda, L. Mearns, C. G. Menendez, J. Raisanen, A. Rinke, A. Sarr, and P. Whetton. 2007. Regional climate projections. In: S. Solomon, D. Qin, M. Manning, Z. Chen, M. Marquis, K. B. Avery, M. Tignor, and H. L. Miller [EDs.]. Climate change 2007: the physical science basis. Contribution of Working Group I to the Fourth Assessment Report of the Intergovermental Panel on Climate Change. Cambridge, UK, and New York, NY, USA: Cambridge University Press, $p$. 888-891.

Cook, E. 1985. A time series analysis approach to tree-ring standardization [dissertation]. Tucson, AZ, USA: University of Arizona. $171 \mathrm{p}$.

Cottam, W. P., and G. SteWARt. 1940. Plant succession as a result of grazing and of meadow desiccation by erosion since settlement in 1862. Journal of Forestry 38:613-626

Dalle, G., B. L. Maass, and J. Isselstein. 2006. Encroachment of woody plants and its impact on pastoral livestock production in the Borana lowlands, southern Oromia, Ethiopia. African Journal of Ecology 44:237-246.

Doelling, H. H., R. E. Blackett, A. H. Hamblin, J. D. Powell, and G. L. Pollock. 2000. Geology of Grand Staircase-Escalante National Monument, Utah. In: D. A. Sprinkel, J. Chidsey, T. C. Chidsey, Jr., and P. B. Anderson [eds.]. Geology of Utah's parks and monuments. Utah Geological Association. p. $1-43$.

EISENHART, K. S. 2004. Historic range of variability of piñon-juniper woodlands of western Colorado [thesis]. Boulder, CO, USA: University of Colorado. 86 p.

Fensham, R. J., R. J. Fairfax, and S. R. Archer. 2005. Rainfall, land use and woody vegetation cover change in semi-arid Australian savanna. Journal of Ecology 93:596-606

Floyd, M. L., D. D. Hanna, and W. H. Romme. 2004. Historical and recent fire regimes in pinon-juniper woodlands on Mesa Verde, Colorado, USA. Forest Ecology and Management 198:269-289.

Floyd, M. L., W. H. Romme, and D. D. Hanna. 2000. Fire history and vegetation pattern in Mesa Verde National Park, Colorado, USA. Ecological Applications 10:1666-1680.

Floyd, M. L., W. H. Romme, D. Hanna, M. Winterowd, and J. Spence. 2008. Fire history of pinyon-juniper woodlands on Navajo Point, Glen Canyon National Recreation Area. Natural Areas Journal 28:26-36.

ForcelLA, F. 1981. Ovulate cone production in pinyon: negative exponential relationship with late summer temperature. Ecology 62:488-491.

FritTs, H. C. 2001. Tree rings and climate. Caldwell, NJ, USA: Blackburn Press. $576 \mathrm{p}$.

Fritts, H. C., D. G. Smith, J. W. Cardis, and C. A. Budelsky. 1965. Tree-ring characteristics along a vegetation gradient in northern Arizona. Ecology 46:393-401.

Gray, S. T., J. L. Betancourt, S. T. Jackson, and R. G. Eddy. 2006. Role of multidecadal climate variability in a range extension of pinyon pine. Ecology 87:1124-1130.

Guenther, D., T. J. Stohlgren, and P. Evangelista. 2004. A comparison of a nearrelict site and a grazed site in a pinyon-juniper community in the Grand Staircase-Escalante National Monument, Utah. In: C. Van Riper and K. L. Cole [EDS.]. The Colorado Plateau: cultural, biological and physical research. Tucson, AZ, USA: University of Arizona Press. p. 153-162.

Harris, A. T., G. P. Asner, and M. E. Mlller. 2003. Changes in vegetation structure after long-term grazing in pinyon-juniper ecosystems: integrating imaging spectroscopy and field studies. Ecosystems 6:368-383.

Hereford, R., R. H. Webb, and S. Graham. 2002. Precipitation history of the Colorado Plateau region, 1900-2000. Tucson, AZ, USA: US Geological Survey Fact Sheet 119-02. p. 4

HoLmes, R. L. 1983. Computer-assisted quality control in tree-ring dating and measurement. Tree-Ring Bulletin 43:69-78.
Jackson, S. T., J. L. Betancourt, M. E. Lyford, S. T. Gray, and K. A. Rylander. 2005. A 40,000-year woodrat-midden record of vegetational and biogeographical dynamics in north-eastern Utah, USA. Journal of Biogeography 32:10851106.

Jacobs, B. F., W. H. Romme, and C. D. Allen. 2008. Mapping "old" vs. "young" piñon-juniper stands with a predictive topo-climatic model. Ecological Applications 18:1627-1641.

Jost, L. 1993. A simple distance estimator for plant density in nonuniform stands. Available at: http://www.loujost.com/Statistics\%20and\%20Physics/PCQ/ PCQDLS.htm. Accessed 2 March 2006.

Madany, M. H., and N. E. West. 1983. Livestock grazing fire regime interactions within montane forests of Zion National-Park, Utah. Ecology 64:661-667.

Mason, L. R., H. M. Andrews, J. A. Carley, and E. D. HaAcke. 1967. Vegetation and soils of No Man's Land Mesa relict area, Utah. Journal of Range Management 20:45-49.

MilLeR, M. E. 2008. Broad-scale assessment of rangeland health, Grand StaircaseEscalante National Monument, USA. Rangeland Ecology \& Management 61:249-262.

MilleR, R. F., AND J. A. Rose. 1999. Fire history and western juniper encroachment in sagebrush steppe. Journal of Range Management 52:550-559.

Miller, R. F., And P. E. Wigand. 1994. Holocene changes in semiarid pinyon-juniper woodlands. Bioscience 44:465-474.

Ni, F. B., T. Cavazos, M. K. Hughes, A. C. Comrie, and G. Funkhouser. 2002. Coolseason precipitation in the southwestern USA since AD 1000: comparison of linear and nonlinear techniques for reconstruction. International Journal of Climatology 22:1645-1662.

Nowak, C. L., R. S. Nowak, R. J. Tausch, and P. E. Wigand. 1994. A 30,000 year record of vegetation dynamics at a semiarid locale in the Great Basin. Journal of Vegetation Science 5:579-590.

ORVIS, K. H., AND H. D. GRIsSino-MaYeR. 2002. Standardizing the reporting of abrasive papers used to surface tree-ring samples. Tree-Ring Research 58:47-50.

Phillips, F. J. 1909. A study of pinon pine. Botanical Gazette 48:216-223.

Pieper, R. D. 1994. Ecological implications of livestock grazing. In: M. Vavra, W. A. Laycock, and R. D. Pieper [EDs.]. Ecological implications of livestock herbivory in the West. Denver, CO, USA: Society for Range Management. p. 177-211.

Plummer, F. G. 1904. Forest conditions in the Black Mesa Forest Reserve, Arizona. Washington, DC, USA: US Geological Survey Professional Paper 23, Series H, Forestry. $62 \mathrm{p}$.

PollaRd, J. H. 1971. Distance estimators of density in randomly distributed forests. Biometrics 27:991-1002.

Romme, W. H., C. D. Allen, J. D. Balley, W. L. Baker, B. T. Bestelmeyer, P. M. Brown, L. Elsenhart, D. W. Floyd-Hanna, B. F. Huffman, B. F. Jacobs, R. F. Millerer, E. H. Muldavin, T. W. Swetnam, R. J. Tausch, and P. J. Weisberg. 2008. Historical and modern disturbance regimes, stand structures, and landscape dynamics in piñon-juniper vegetation of the western U. S. Fort Collins, CO, USA: Colorado Forest Restoration Institute. $37 p$

Savage, M., P. M. Brown, and J. Feddema. 1996. The role of climate in a pine forest regeneration pulse in the southwestern United States. Ecoscience 3:310-318.

Schlecht, E., U. Dicknoefer, E. Gumpertsberger, and A. Buerkert. 2009. Grazing itineraries and forage selection of goats in the Al Jabal al Akhdar mountain range of northern Oman. Journal of Arid Environments 73:355-363.

Seager, R., M. F. Ting, I. Held, Y. Kushnir, J. Lu, G. Vecchi, H. P. Huang, N. Harnik, A. Leetmaa, N. C. Lau, C. H. Li, J. Velez, and N. Nalk. 2007. Model projections of an imminent transition to a more arid climate in southwestern North America. Science 316:1181-1184.

Shaw, J. D. 2006. Drought-related mortality in pinyon-juniper woodlands: a test case for the FIA Annual Inventory System. In: R. E. McRoberts, G. A. Reams, P. C. Van Duesen, and W. McWilliams [EDs.]. Proceedings of the Sixth Annual Forest Inventory and Analysis Symposium. Washington, DC, USA: US Department of Agriculture Forest Service. p. 65-71.

Silva, J. F., A. Zambrano, and M. R. Farinas. 2001. Increase in the woody component of seasonal savannas under different fire regimes in Calabozo, Venezuela. Journal of Biogeography 28:977-983. 
Soulé, P. T., P. A. Knapp, and H. D. Grissino-Mayer. 2003. Comparative rates of western juniper afforestation in south-central Oregon and the role of anthropogenic disturbance. Professional Geographer 55:43-55.

SPSS [COMPUTER PRogram]. 2007. Version 16.0 for Windows. Chicago, IL, USA: SPSS Inc.

StoKes, M. A., AND T. L. Smiley. 1968. An introduction to tree-ring dating. Chicago, IL, USA: University of Chicago Press. 73 .

TAusch, R. J. 1999. Historic pinyon and juniper woodland development. In: S. B. Monsen and R. Stevens [EDS.]. Proceedings of the Conference on Ecology and Management of Pinyon-Juniper Communities within the Interior West. Ogden, UT, USA: US Department of Agriculture, Forest Service, Rocky Mountain Research Station. p. 12-19.

TAUSCH, R. J., AND R. S. Nowak. 1999. Fifty years of ecotone change between shrub and tree dominance in the Jack Springs Pinyon Research Natural Area. In: E. D. McArthur, W. K. Ostler, and C. L. Wambolt [EDs.]. Proceedings of the Conference on Shrubland Ecotones. Ogden, UT, USA: US Department of Agriculture, Forest Service, Rocky Mountain Research Station. p. $1-7$.

Tefera, S., H. A. Snyman, and G. N. Smit. 2007. Rangeland dynamics of southern Ethiopia: (2). Assessment of woody vegetation structure in relation to land use and distance from water in semi-arid Borana rangelands. Journal of Environmental Management 85:443-452.

Van Auken, 0. W. 2000. Shrub invasions of North American semiarid grasslands. Annual Review of Ecology and Systematics 31:197-215.

Van Devender, T. R., and W. G. Spaulding. 1979. Development of vegetation and climate in the southwestern United States. Science 204:701-710.

Wall, T. G., R. F. Miller, and T. J. SvejCar. 2001. Juniper encroachment into aspen in the Northwest Great Basin. Journal of Range Management 54:691-698.

Weisberg, P. J., E. Lingua, and R. B. Pillal. 2007. Spatial patterns of pinyon-juniper woodland expansion in central Nevada. Rangeland Ecology \& Management 60:115-124.

Wigand, P. E., M. L. Hemphill, S. E. Sharpe, and S. M. Patra. 1995. Great Basin semi-arid woodland dynamics during the late quaternary. In: W. J. Waugh [ED.]. Proceedings of the workshop on climate change in the four corners and adjacent regions: implications for environmental restoration and land-use planning. Grand Junction, CO, USA: Mesa State College. p. 51-69.

Zlotin, R. I., and R. R. Parmenter. 2008. Patterns of mast production in pinyon and juniper woodlands along a precipitation gradient in central New Mexico (Sevilleta National Wildlife Refuge). Journal of Arid Environments 72:1562-1572. 